\title{
Implementasi Metode National Institute of Justice (NIJ) Pada Fitur TRIM SOLID STATE DRIVE (SSD) Dengan Objek Eksperimental Sistem Operasi Windows, Linux dan Macintosh
}

\author{
Rizdqi Akbar Ramadhan ${ }^{1}$, Desti Mualfah ${ }^{2}$ \\ Jurusan Teknik Informatika, Fakultas Teknik, Universitas Islam Riau ${ }^{1}$ \\ Jurusan Teknik Informatika, Fakultas Ilmu Komputer, Universitas Muhamadiyah Riau ${ }^{2}$ \\ rizdqiramadhan@eng.uir.ac.id ${ }^{1}$, destimualfah@umri.ac.id ${ }^{2}$
}

\begin{tabular}{l} 
Article Info \\
\hline History: \\
Dikirim 30 Oktober 2020 \\
Direvisi 03 November 2020 \\
Diterima 17 November 2020 \\
\hline
\end{tabular}

\section{Kata Kunci :}

Solid State Drive

Digital Forensik

Investigation

Recovery Files

Operating System

\begin{abstract}
Abstrak
Solid State Drive (SSD) merupakan solusi terkni untuk mempercepat pemrosesan data dari berbagai komputer desktop yang bersifat multiplatform. Fitur TRIM yang ada pada SSD berguna untuk menghilangkan garbage data yang dihapus permanen oleh user, dimana metode ini memiliki benefit untuk memperpanjang usia pakai dari perangkat SSD. Kontradiksi dari penggunaan metode ini adalah sulitnya bagi investigator forensik untuk melakukan recovery data yang telah terhapus apabila terjadi praktek cyber crime dalam kasus barang bukti berupa komputer dengan storage SSD. Objek eksperimen dalam penelitian ini berdasarkan perspektif sistem operasi mainstream yaitu Windows, Linux dan Macintosh yang terinstall pada SSD dimana pada masing-masing sistem operasi dilakukan simulasi penghapusan data yang tersimpan dengan perbandingan konfigurasi TRIM enable dan TRIM disable. Metode Digital Forensik yang diimplementasikan pada hal ini adalah National Intitute of Justice (NIJ) dimana metode ini berlaku sebagai acuan dalam praktek Digital Forensik pada penelitian ini. Perangkat lunak SLEUTH KIT Autopsy merupakan perangkat Digital Forensik yang digunakan dalam perspektif investigator dalam akusisi dan analisis barang bukti SSD pada simulasi kasus penelitian ini. Novelti yang didapatkan pada konten penelitian adalah sistem operasi yang menjadi objek eksperimen merupakan sistem operasi Windows, Linux, dan Macintosh rilis terkini yang tentunya memiliki potensi yang besar dalam hal eksplorasi, khususnya Digital Forensik. Windows memiliki peluang hasil recovery paling besar diantara 2 sistem operasi lainnya dalam penelitian ini.
\end{abstract}

(C) This work is licensed under a Creative Commons AttributionShareAlike 4.0 International License.

\section{Koresponden:}

Rizdqi Akbar Ramadhan

Program Studi Teknik Informatika, Fakultas Teknik

Universitas Islam Riau

Jalan Kaharudin Nasution, Pekanbaru, Indonesia, 28284

Email : rizdqiramadhan@eng.uir.ac.id 


\section{PENDAHULUAN}

Teknologi komputer mengalami perkembangan yang pesat dalam dasawarsa terakhir. Komputer Forensic yang menjadi bidang ilmu khususnya mempelajari tentang anatomi komputer itu sendiri juga berbanding lurus dengan kemajuan teknologi tersebut [1]. Penelitian ini lebih menekankan kepada Investigasi Forensik secara praktikal dibandingkan teoritis namun dengan menggunakan kerangka kerja yang lazim digunakan, yaitu NIJ (National Institute of Justice). Dalam penelitian ini penulis lebih menekankan pendekatan teknis praktek investigasi Forensik Digital menggunakan framewok diluar aspek hukumnya. Komponen komputer secara esensial terdiri perangkat keras dan perangkat lunak [2] yang dalam ilmu komputer forensik perangkat keras menjadi objek penelitian secara anatomi. Perangkat lunak selain berperan sebagai objek penelitian secara anatomi dan logic disisi lainnya juga berperan sebagai perangkat pendukung (tools). Tools pendukung yang penulis gunakan dalam implementasi Digital Forensic dalam penelitian ini adalah Sleuth Kit Autopsy dan guna proses imaging akan menggunakan FTK Imager.

Secara organisasi dan arsitektur komputer, dalam hal ini adalah CPU (central processing unit) terdiri dari komponen inti berupa Processor, Random Access Memory (RAM), serta media penyimpanan non volatile berupa storage yang sering disebut Hardisk [3]. Storage sendiri [4] dewasa ini terbagi atas dua spesifikasi yaitu HDD (Harddisk Drive) dan SDD (Solid State Drive). Teknologi terbaru komputer dituntut akan kecepatan akses dalam pengoperasiannya, salah satunya dengan penggunaan Solid State Drive yang menggantikan posisi Hardisk Drive dalam media penyimpanan data. SSD memiliki fitur yang bernama fitur TRIM. Fitur TRIM memungkinkan OS (operating system) untuk mengintruksikan SSD terkait block mana saja yang sudah tidak digunakan [5]. Sehingga ketika akan ditulis, tidak perlu melakukan proses penghapusan terlebih dahulu. Fitur TRIM membantu menjaga agar performa Write di drive SSD terus terjaga baik. Fungsi TRIM menghapus blok yang telah ditandai untuk dihapus oleh sistem operasi. Menurut kacamata forensika digital, kontradiksi dari penggunaan SSD dengan fitur TRIM nya adalah "fungsi TRIM memiliki efek negatif pada analisis forensik khususnya pada recovery data"[6]. Penghapusan yang dilakukan tidak dijamin terangkat kembali karena sistem controller memori pada SSD telah memutuskan kapan dan berapa banyak blok ditandai untuk penghapusan [7].

Sederhananya, TRIM yang telah ter-enable berfungsi untuk memusnahkan garbage data yang telah dihapus [8]. Berdasarkan studi literatur dari penelitian-penelitian terdahulu yang digunakan sebagai pendukung dari penelitian ini, selalu ditemukan eksperimen pada SSD Forensik dengan menggunakan tools yang lazim digunakan dalam melakukan recovery data. Sayangnya, dari eksperimen-eksperimen sebelumnya terlihat bahwa fungsi TRIM selalu menjadi tantangan dalam recovery data. Pada kasus recovery data menggunakan HDD konvensional, [9] proses recovery data secara garis besar dapat mengangkat kembali Bukti Digital yang diperlukan guna kebutuhan investigasi. Dalam penelitian ini SSD menjadi objek penelitian yang mewakili perangkat keras serta Operating System Windows, Linux dan Macintosh sebagai objek eksperimen yang mewakili perangkat lunak. Parameter yang diukur dalam penelitian ini berupa kemampuan Sleuth Kit Autopsy dalam recovery file serta durasi waktu yang dibutuhkannya dalam analisis dari masing-masing sistem operasi Windows, Linux, dan Macintosh beserta file didalamnya.

\section{METODE PENELITIAN}

Penelitian dilakukan dengan simulasi skenario berdasarkan 2 perspektif, yaitu perspektif investigator dan lainnya adalah perspektif pelaku kejahatan digital yang dikemas dalam satu garis waktu. Perspektif pelaku dalam skenario melakukan manipulasi jejak digital menggunakan SSD, selanjutnya perspektif investigator dalam mencari dan analisa bukti digital dari SSD skenario pelaku. Tahapan penelitian yang dilakukan adalah menggunakan pendekatan metodologi teknik statik forensik berdasarkan acuan NIJ (Natinal Institute of Justice) yang dapat dilihat pada gambar 1. Tahapan metode dari NIJ ini terbagi menjadi lima tahapan yakni identification, collection, examination, analysis, dan reporting [10], secara lengkap dipaparkan sebagai berikut: Tahap identification atau tahap identifikasi merupakan kegiatan pemilahan barang bukti tindak kejahatan 
digital dan pemilahan data-data untuk mendukung proses penyidikan dalam rangka pencarian barang bukti kejahatan digital. Pada tahap ini didalamnya terdapat proses identifikasi, pelabelan, perekaman, untuk menjaga keutuhan barang bukti. Tahap collection atau tahap pengumpulan merupakan serangkaian kegiatan mengumpulkan data-data untuk mendukung proses penyidikan dalam rangka pencarian barang bukti kejahatan digital. Pada tahap ini didalamnya terdapat proses pengambilan data dari sumber data yang relevan dan menjaga integritas barang bukti dari perubahan [11]. Tahap examination atau tahap pemeriksaan ini merupakan tahap pemeriksaan data yang dikumpulkan secara forensik baik secara otomatis atau manual, serta memastikan bahwa data yang didapat berupa file tersebut asli sesuai dengan yang didapat pada tempat kejadian kejahatan komputer, untuk itu pada file digital perlu dilakukan identifikasi dan validasi file dengan teknik hashing [12]. Hash merupakan suatu kode dari hasil enkripsi yang umumnya terdiri dari huruf maupun angka yang acak. Fungsi Hash dalam digital forensik digunakan untuk kalkulasi serta analisa duplikasi di sebuah arsip komputer yang besar. Ekstensi hash yang digunakan dalam penelitian ini adalah MD5.

Tahap analysis atau tahap meneliti ini dilakukan setelah mendapatkan file atau data digital yang diinginkan dari proses pemeriksaan sebelumnya, selanjutnya data tersebut dianalisis secara detail dan komprehensif dengan metode yang dibenarkan secara teknik dan hukum untuk dapat membuktikan data tersebut. Hasil analisis terhadap data digital selanjutnya disebut digunakan sebagai barang bukti digital serta dapat dipertanggung jawabkan secara ilmiah dan secara hukum. Tahap reporting atau tahap pelaporan dilakukan setelah diperoleh barang bukti digital dari proses pemeriksaan dan dianalisis [13]. Selanjutnya pada tahap ini dilakukan pelaporan hasil analisis yang meliputi penggambaran tindakan yang dilakukan, penjelasan mengenai tools, dan metode yang digunakan, penentuan tindakan pendukung yang dilakukan, dan memberikan rekomendasi untuk perbaikan kebijakan, metode, tools, atau aspek pendukung lainnya pada proses tindakan digital forensik [14].

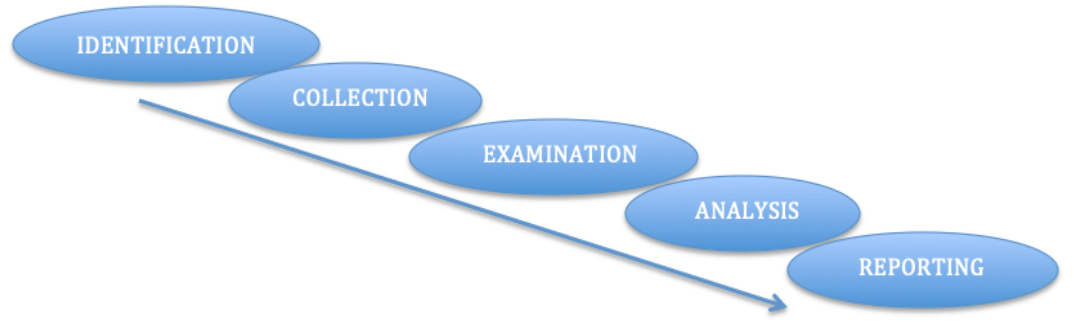

Gambar 1. National Institue of Justice (NIJ) Methodology

\subsection{Perangkat Keras dan Perangkat Lunak beserta Environment Lainnya}

Pengumpulan yang meliputi hardware dan software dalam penelitian ini terbagi pada 2 perspektif. Perspektif yang pertama adalah perspektif investigator yang menggunakan perangkat keras berupa Asus TUF Gaming FX505DD yang dapat dilihat pada tabel 1, serta perangkat lunak penunjang implementasi digital forensik berupa FTK Imager, Hash Calculator dan SLEUTH KIT Autopsy. Selanjutnya untuk perspektif yang kedua adalah perspektif barang bukti yang akan diambil bukti digitalnya. Pada perspektif kedua, perangkat keras yang digunakan adalah Solid State Drive (SSD) Midasforce 120GB yang sudah mendukung fitur TRIM enable atau TRIM disable. Masing-masing SSD akan terinstall 3 sistem operasi yang berbeda; Windows 10 Profesional, Linux Ubuntu, dan Macintosh OSX Catalina. Ketiga sistem operasi yang dipilih merupakan sistem operasi yang umum digunakan dalam komputasi desktop pribadi maupun skala workstation. Hal lain terkait sistem operasi yang menjadi objek eksperimen penelitian ini telah diperbarui melalui pembaruan paling mutakhir dalam kuartal ke-3 tahun ini. Fakta ini bertujuan sebagai novelti dalam proses beserta luaran yang dapat disimpulkan setelah eksperimen berjalan. 
Tabel 1. Perbandingan Antara Perspetif 1 dan Perspektif 2

\begin{tabular}{|c|c|c|}
\hline Perspective & Hardware & Software \\
\hline 1 & $\begin{array}{l}\text { ASUS Tuf } \\
\text { Gaming } \\
\text { FX505DD }\end{array}$ & $\begin{array}{c}\text { FTK Imager, Hash Calculator, SLEUTH KIT } \\
\text { Autopsy. }\end{array}$ \\
\hline 2 & $\begin{array}{c}3 \text { units of SSD } \\
\text { Midasforce } \\
\text { 120GB }\end{array}$ & $\begin{array}{l}\text { Windows } 10 \text { Pro x64, Linux Ubuntu amd64, } \\
\text { Macintosh OSX Catalina 10.15.4 64bit. }\end{array}$ \\
\hline
\end{tabular}

\subsection{Konsep Teori}

Pada penelitian ini mengadaptasi dan mengimplementasikan metode analisa forensik dari National Institute of Justice (NIJ). Metode ini untuk menjelaskan bagaimana tahapan penelitian yang akan dilakukan sehingga dapat diketahui alur dan langkah-langkah penelitian secara sistematis sehingga dapat dijadikan pedoman dalam menyelesaikan permasalahan yang ada [15]. Simulasi dan skenario dilakukan secara eksplisit terhadap SSD dengan 2 konfigurasi yaitu; TRIM enable dan TRIM disable. Hasil yang diharapkan secara garis besar untuk mengetahui perbedaan karakteristik dari masing-masing konfigurasi terhadap masing-masing sistem operasi serta mengetahui jangka waktu SLEUTH KIT Autopsy dalam melakukan analisis sistem dengan ukuran storage 120GB pada Windows, Linux, dan Macintosh. Gambar 2 menjelaskan bagaimana simulasi akan dijalankan berdasarkan 2 perspektif:

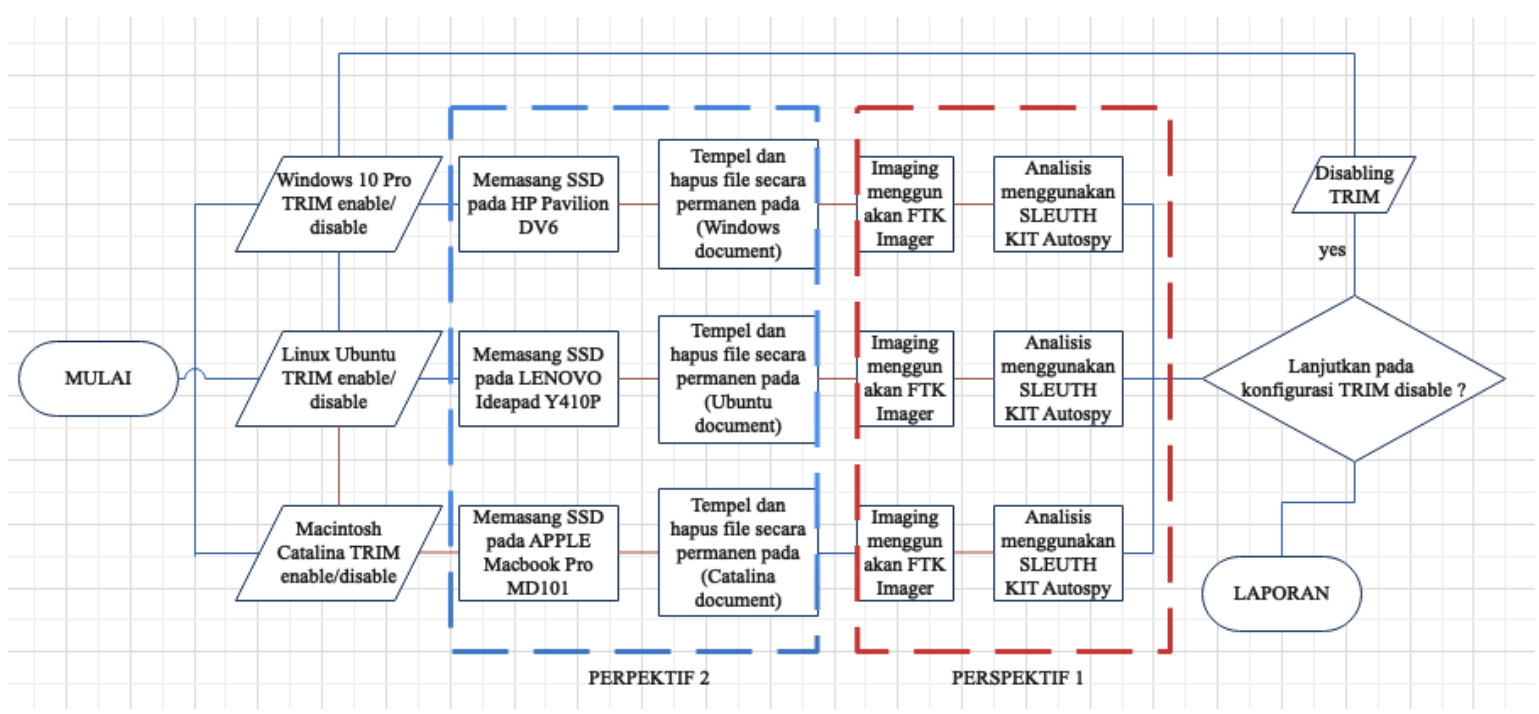

Gambar 2. Riset Metodologi dan Analisa Simulasi

\subsection{Pengumpulan Data}

Dalam melakukan tahapan riset pada perspektif kedua, terdapat 14 sampel file yang umum digunakan dan bersifat kompatibilitas secara global. Masing-masing file di-klasifikasikan atas 7 ekstensi yang berbeda yang dapat dilihat pada Tabel 2. Parameter ukuran file serta nilai hash yang tertampil akan menjadi salah satu sudut pandang analisa karena sifatnya yang rentan terhadap perubahan volume.

Tabel 2. Sampel File Objek Simulasi Forensik

\begin{tabular}{cccc}
\hline Materials & Extensions & Size & Hash Value \\
\hline LAGU1 & $\mathrm{mp3}$ & $4,18 \mathrm{MB}$ & afbae4d76a5165f3f949eb45c3df9a82 \\
LAGU2 & $\mathrm{mp3}$ & $3,48 \mathrm{MB}$ & 6c7b092771ff94db8c57ff9cde3760e5 \\
\hline
\end{tabular}




\begin{tabular}{ccrr} 
DOKUMEN1 & docx & $50,3 \mathrm{~KB}$ & f93ccfee75e8c413094f178afce6d436 \\
DOKUMEN2 & docx & $660 \mathrm{~KB}$ & $\mathrm{c} 9 \mathrm{a} 998879 \mathrm{~b} 076 \mathrm{f} 106803582 \mathrm{ab} 5 \mathrm{fa} 4 \mathrm{~d} 10$ \\
FILE1 & pdf & $203 \mathrm{~KB}$ & $\mathrm{c} 21 \mathrm{~d} 96078 \mathrm{a} 7 \mathrm{c} 5074 \mathrm{fb} 1423987 \mathrm{~b} 77 \mathrm{~b} 7 \mathrm{~d} 7$ \\
FILE2 & pdf & $156 \mathrm{~KB}$ & $615 \mathrm{e} 1 \mathrm{a} 485939664 \mathrm{dda} 4 \mathrm{bf} 2 \mathrm{e} 3 \mathrm{bb} 91 \mathrm{c} 220$ \\
FORM1 & xlsx & $329 \mathrm{~KB}$ & $621 \mathrm{~d} 21 \mathrm{e} 4182 \mathrm{~b} 6 \mathrm{f} 760519 \mathrm{e} 12 \mathrm{f} 970292 \mathrm{ef}$ \\
FORM2 & xlsx & $14,1 \mathrm{~KB}$ & $10477 \mathrm{bc} 204 \mathrm{af} 16 \mathrm{dc} 6 \mathrm{bff} 9 \mathrm{~d} 298 \mathrm{fc} 2058 \mathrm{e}$ \\
GAMBAR1 & jpg & $769 \mathrm{~KB}$ & $33 \mathrm{ac} 33365869548 \mathrm{ce} 96 \mathrm{c} 8 \mathrm{~b} 6 \mathrm{fd} 90 \mathrm{~b} 25 \mathrm{ab}$ \\
GAMBAR2 & jpg & $49,0 \mathrm{~KB}$ & $\mathrm{a} 22 \mathrm{~d} 7 \mathrm{~b} 5 \mathrm{~b} 268 \mathrm{df} 6476 \mathrm{f} 06213 \mathrm{c} 11 \mathrm{ffd} 4 \mathrm{a} 9$ \\
SLIDE1 & pptx & $228 \mathrm{~KB}$ & fb9b95c3cb21ed4ca4edff74df351862 \\
SLIDE2 & pptx & $402 \mathrm{~KB}$ & d0fcfadf940310851e0e820aa6eafb60 \\
FILM1 & bluray & $1,67 \mathrm{~GB}$ & f81b311b93e1d8d20ea8462f230bb807 \\
FILM2 & bluray & $1,81 \mathrm{~GB}$ & e6d2084adee34d15efa804754b74ab6 \\
\hline
\end{tabular}

Selanjutnya setelah menentukan sejumlah file yang telah ditetapkan, file-file tersebut akan disalin kepada 3 perangkat SSD yang masing-masing dibedakan atas sistem operasi yang terdapat pada Gambar 3. File sampel akan diletakkan pada direktori documents yang terdapat seragam pada 3 sistem operasi tersebut. Pada langkah pertama, konfigurasi TRIM diatur dalam posisi enable terlebih dahulu dan selanjutnya dilakukan penghapusan 14 file sampel secara permanen dengan perintah yang variatif dari masing-masing sistem operasi.

Tabel 3. Perbandingan Resource Memori A dan B

\begin{tabular}{ccc}
\hline Operating System & Enabling TRIM & Disabling TRIM \\
\hline Windows 10 & fsutil behavior set & fsutil behavior set \\
& DisableDeleteNotify 0 & DisableDeleteNotify 1 \\
Linux Ubuntu & sudo fstrim -v / & sudo rm \\
& /etc/cron.weekly/fstrim \\
MacOS Catalina & sudo trimforce enable & sudo trimforce disable \\
\hline
\end{tabular}

Pada Tabel 3 ditampilkan perintah-perintah konfigurasi enabling dan disabling TRIM yang terdapat pada masing-masing sistem operasi. Untuk setiap sistem operasi, perintah dijalankan pada CLI (Command Line Interface) [16]. Secara terminologi arsitektur komputer, perintah ini merupakan set instruksi sistem operasi kepada controller SSD. Metode seperti tidak berlaku pada media penyimpanan konvensional, yaitu Hardisk Drive [17].

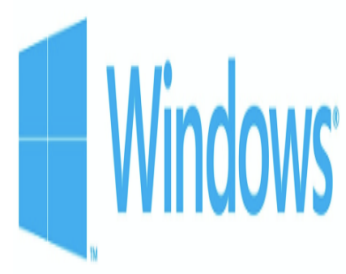

(a)

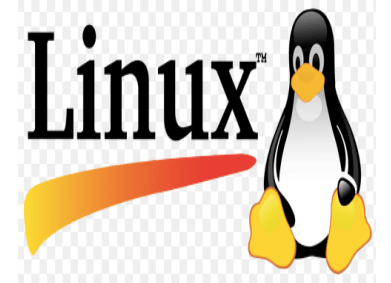

(b)

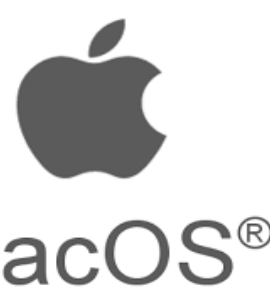

(c)

Gambar 3. Sistem Operasi Objek Penelitian (a) Windows10 Pro (b) Linux Ubuntu (c) MacOS 10.15.4 Catalina

\section{HASIL DAN PEMBAHASAN}

Terdapat 3 perangkat lunak utama dalam metode riset sebagai perspektif 2 yaitu, Hash Calculator yang digunakan untuk menghitung nilai hash dari masing-masing file, hasil imaging, 
serta hasil autopsy. Berikutnya adalah FTK Imager yang merupakan perangkat lunak untuk kontribusinya dalam melakukan imaging dari 3 SSD yang digunakan. Selanjutnya, SLEUTH KIT Autopsy yang berjalan pada sistem operasi Windows dengan spesifikasi perangkat keras Processor AMD RYZEN dengan jangkauan clockspeed di-angka 2.1-3.7Ghz serta RAM sebesar 8GB ddr4. Berdasarkan spesifikasi tersebut, durasi dalam parameter jam dan menit pada SLEUTH KIT Autopsy dalam melakukan eksaminasi dari awal eksekusi hingga tahapan optimalisasi dalam recovery 14 sampel file dalam masing-masing sistem operasi pada SSD sebesar 120GB dapat dilihat pada Tabel 4:

Tabel 4. Hasil Perbandingan Durasi Analisis Sistem Autopsy

\begin{tabular}{cccc}
\hline Konfigurasi & $\begin{array}{c}\text { Windows } 10 \\
\text { x64 }\end{array}$ & $\begin{array}{c}\text { Linux Ubuntu } \\
\text { amd64 }\end{array}$ & $\begin{array}{c}\text { Macintosh } \\
\text { OSX Catalina }\end{array}$ \\
\hline TRIM & 18 jam 26 & 11 jam 31 & 77 jam 19 \\
enable & menit & menit & menit \\
TRIM & 19 jam 45 & 20 jam 10 & 74 jam 32 \\
disable & menit & menit & menit \\
\hline
\end{tabular}

Selanjutnya dalam tahapan analisis yang didapatkan dari objek sistem operasi Windows 10 Professional dengan arsitektur 64bit dapat dilihat pada Tabel 5. Pada konfigurasi TRIM enable, keseluruhan dari 14 file dapat terdeteksi kembali namun dengan status corrupt. Status ini menyebabkan nilai hash yang berbeda antara pre-autopsy dengan post-autopsy. Dengan ini dapat disimpulkan bahwa file-file tersebut berubah bentuk dan menjadi orphan files. Dalam konfigurasi TRIM disable , 12 dari 14 file dapat recovery kembali dengan nilai hash yang sama. Sedangkan file DOKUMEN 1 yang berstatus corrupt terdapat perubahan nilai hash yang semulanya bernilai c9a998879b076f106803582ab5fa4d10 menjadi f46940555900b45a14bb633ee744cdb6 serta file bernama FILE1 berekstensi PDF yang awalnya bernilai c21d96078a7c5074fb1423987b77b7d7 berubah menjadi 19cbdc4f6e7e8bec2fbb0eb952046c9c.

Tabel 5. Hasil Analisis Sistem Operasi Windows 10

\begin{tabular}{|c|c|c|c|}
\hline TRIM enable & Status & Hash Value (pre-autopsy) & Hash Value (post-autopsy) \\
\hline LAGU1 & corrupt & afbae4d76a516....c3df9a82 & e126e1323ec1a039f...6aae1358e \\
\hline LAGU2 & corrupt & 6c7b092771ff94.......760e 5 & 3b0dd842213775cc6.....b4a8e46 \\
\hline DOKUMEN1 & corrupt & f93ccfee 75 e $8 c . . . . . . . e 6 d 436$ & $\mathrm{ab} 260777 \mathrm{~b} 35 \mathrm{c} 17 \mathrm{~d} 3 \mathrm{fca} \ldots . . . . \mathrm{d} 528 \mathrm{c}$ \\
\hline DOKUMEN2 & corrupt & c9a998879b0 ......b5fa4d 10 & $73 \mathrm{e} 37 \mathrm{c} 54936 \mathrm{f0} 4 \mathrm{fe} 96 \ldots \ldots \ldots . .14 \mathrm{~d} 5$ \\
\hline FILE1 & corrupt & $\mathrm{c} 21 \mathrm{~d} 96078 \ldots \ldots .77 \mathrm{~b} 7 \mathrm{~d} 7$ & $77 \mathrm{f} 270318 \mathrm{~d} 54 \mathrm{c} 1 \mathrm{c} 322 \mathrm{e} . \ldots \ldots . .8 \mathrm{af0} 7$ \\
\hline FILE2 & corrupt & $615 \mathrm{e} 1 \mathrm{a} 485939 \ldots . .91 \mathrm{c} 220$ & ba4942c353da3e0be6b6....b093b \\
\hline FORM1 & corrupt & $621 \mathrm{~d} 21 \mathrm{e} 418 \ldots . . .0292 \mathrm{ef}$ & c4a51baa1e387fc02272......730e \\
\hline FORM2 & corrupt & $10477 \mathrm{bc} 204 \mathrm{af1} \ldots . . .2058 \mathrm{e}$ & b182b927e3b6dee7c.........3931e \\
\hline GAMBAR1 & corrupt & $33 \mathrm{ac} 333658695 \ldots . . \mathrm{b} 25 \mathrm{ab}$ & 66f35d3e62996ed7ab.........dee6b \\
\hline GAMBAR2 & corrupt & a22d7b5b268df64......fd4a9 & 66ff57ab16bbfa39f5a.......49751 \\
\hline SLIDE1 & corrupt & fb $9 b 95 \mathrm{c} 3 \mathrm{cb} 2 \ldots \ldots 1862$ & ed716fb3fe $5 \mathrm{f} 6 \mathrm{~d} 2163 \mathrm{~cd} . . . . . .1 \mathrm{e} 2 \mathrm{e}$ \\
\hline SLIDE2 & corrupt & d0fcfadf94031085...ffb60 & $262 \mathrm{c} 01 \mathrm{ff} 1 \mathrm{cc} 692018 \mathrm{~b} 7 \mathrm{~b} \ldots \ldots . .22 \mathrm{fe}$ \\
\hline FILM1 & corrupt & f81b311b93e1.....b807 & b2e7f69ba8560bfcf12.......692fa \\
\hline FILM2 & corrupt & e6d2084a9de.....4ab6 & fdd 74 fba92b1d1438bc27......493 \\
\hline TRIM disable & Status & Hash Value (pre-autopsy) & Hash Value (post-autopsy) \\
\hline LAGU1 & recovered &..$d f 9 a 82$ & $\mathrm{df9} 982$ \\
\hline LAGU2 & recovered & $6 \mathrm{c} 7 \mathrm{~b} 092771 \mathrm{ff} . . .3760 \mathrm{e} 5$ & 6c7b092771ff....3760e5 \\
\hline DOKUMEN1 & recovered & f93 ccfee.....e6d436 & f93 ccfee.....e6d436 \\
\hline DOKUMEN2 & corrupt & c9a998879b0 ...5fa 4d10 & $\mathrm{f} 46940555900 \mathrm{~b} 45 \mathrm{a} 14 \mathrm{~b} \ldots . .44 \mathrm{cdb} 6$ \\
\hline FILE1 & corrupt & $\mathrm{c} 21 \mathrm{~d} 96078 \ldots . .77 \mathrm{~b} 7 \mathrm{~d} 7$ & $19 \mathrm{cbdc} 4 \mathrm{f} 6 \mathrm{e} 7 \mathrm{e} 8 \mathrm{bec} 2 \mathrm{fb} . \ldots . .046 \mathrm{c} 9 \mathrm{c}$ \\
\hline
\end{tabular}

Rizdqi Akbar Ramadhan, Implementasi Metode NIJ Pada Fitur TRIM Solid State Drive Dengan Objek Sistem Operasi Windows, Linux, dan Macintosh 


$\begin{array}{crr}\text { FILE2 } & \text { recovered } & \text { 615e1 a485939....91c220 } \\ \text { FORM1 } & \text { recovered } & 621 \mathrm{~d} 21 \mathrm{e} 418 \ldots . . .0292 \mathrm{ef} \\ \text { FORM2 } & \text { recovered } & 10477 \mathrm{bc} 204 \mathrm{af} 1 \ldots . . .2058 \mathrm{e} \\ \text { GAMBAR1 } & \text { recovered } & 33 \mathrm{ac} 333658695 \ldots . . . \mathrm{b} 25 \mathrm{ab} \\ \text { GAMBAR2 } & \text { recovered } & \text { a22d7b5b268df64.....fd4a9 } \\ \text { SLIDE1 } & \text { recovered } & \text { fb9b95c3cb2.....1862 } \\ \text { SLIDE2 } & \text { recovered } & \text { d0fcfadf94031085...fb60 } \\ \text { FILM1 } & \text { recovered } & \text { f81b311b93e1....b807 } \\ \text { FILM2 } & \text { recovered } & \text { e6d2084a9de.....4ab6 }\end{array}$

$615 \mathrm{e} 1 \mathrm{a} 485939 \ldots . . .91 \mathrm{c} 220$
$621 \mathrm{~d} 21 \mathrm{e} 418 \ldots . .0292 \mathrm{ef}$
$10477 \mathrm{bc} 204 \mathrm{af1} \ldots . . .2058 \mathrm{e}$
$33 \mathrm{ac} 333658695 \ldots . . . \mathrm{b} 25 \mathrm{ab}$
$\mathrm{a} 22 \mathrm{~d} 7 \mathrm{~b} 5 \mathrm{~b} 268 \mathrm{df} 64 \ldots . . . \mathrm{fd} 4 \mathrm{a} 9$
fb9b95c3cb2.....1862
d0fcfadf94031085...fb60
f81b311b93e1....b807
e6d2084a9de.....4ab6

Pada tahapan analisis TRIM enable dengan objek sistem operasi Linux Ubuntu dengan arsitektur amd64 pada Tabel 6 ditampilkan bahwa seluruh sampel file simulasi tidak dapat recovery kembali. Metode yang diterapkan sama halnya dengan 2 sistem operasi lainnya dalam penelitian ini. Dapat dianalisa bahwa seluruh file yang hilang mengindikasikan bahwa fitur TRIM enable pada Linux Ubuntu efektif menghilangkan garbage file. Hal ini berdampak signifikan pada investigasi Digital Forensik apabila didapatkan barang bukti berupa SSD dengan sistem operasi Linux Ubuntu. Kemudian pada konfigurasi TRIM disable, terdapat 4 dari 14 sampel file yang dapat dianalisis dengan status corrupt. Pada file bernama DOKUMEN1 terdapat perubahan nilai hash yang pada awal mulanya tercatat bernilai f93ccfee 75e8c413094f178afce6d436 menjadi bernilai 216a0bc703be344a431c1ebab06194a8 serta pada file DOKUMEN2, FORM1 dan FORM2 samasama mendapatkan nilai hash post-autopsy d41d8cd98f00b204e9800998ecf8427e meskipun pada pre-autopsy memiliki nilai hash yang berbeda-beda.

Tabel 6. Hasil Analisis Sistem Operasi Linux Ubuntu

\begin{tabular}{|c|c|c|c|}
\hline TRIM enable & Status & Hash Value (pre-autopsy) & Hash Value (post-autopsy) \\
\hline LAGU1 & disappear & afbae4d76a516....c3df9a82 & - \\
\hline LAGU2 & disappear & 6c7b092771ff94.......760e5 & - \\
\hline DOKUMEN1 & disappear & f93ccfee 75 e $8 c . . . . . . . e 6 d 436$ & - \\
\hline DOKUMEN2 & disappear & c9a998879b0......b5fa4d10 & - \\
\hline FILE1 & disappear & c21d96078.....77b7d7 & - \\
\hline FILE2 & disappear & 615e1a485939....91c220 & - \\
\hline FORM1 & disappear & $621 \mathrm{~d} 21 \mathrm{e} 418 \ldots . . .0292 \mathrm{ef}$ & - \\
\hline FORM2 & disappear & 10477bc204af1.....2058e & - \\
\hline GAMBAR1 & disappear & $33 \mathrm{ac} 333658695 \ldots . . \mathrm{b} 25 \mathrm{ab}$ & - \\
\hline GAMBAR2 & disappear & a22d7b5b268df64......fd4a9 & - \\
\hline SLIDE1 & disappear & fb9b95c3cb2 $2 \ldots . .1862$ & - \\
\hline SLIDE2 & disappear & d0fcfadf94031085...fb60 & - \\
\hline FILM1 & disappear & f81b311b93e1....b807 & - \\
\hline FILM2 & disappear & e6d2084a9de.....4ab6 & - \\
\hline TRIM disable & Status & Hash Value (pre-autopsy) & $\begin{array}{l}\text { Hash Value (post- } \\
\text { autopsy) }\end{array}$ \\
\hline LAGU1 & disappear & afbae4d7....df9a82 & - \\
\hline LAGU2 & disappear & $6 \mathrm{c} 7 \mathrm{~b} 092771 \mathrm{ff} . . .3760 \mathrm{e} 5$ & - \\
\hline DOKUMEN1 & corrupt & f93ccfee.....e6d436 & $216 a 0 b c 703 b \ldots . .94 a 8$ \\
\hline DOKUMEN2 & corrupt & c9a998879b0....5fa4d10 & $\mathrm{d} 41 \mathrm{~d} 8 \mathrm{~cd} 9 . . . . . .8427 \mathrm{e}$ \\
\hline FILE1 & disappear & c21d96078......77b7d7 & - \\
\hline FILE2 & disappear & $615 \mathrm{e} 1 \mathrm{a} 485939 \ldots . .91 \mathrm{c} 220$ & - \\
\hline FORM1 & corrupt & $621 \mathrm{~d} 21 \mathrm{e} 418 \ldots \ldots .0292 \mathrm{ef}$ & $\mathrm{d} 41 \mathrm{~d} 8 \mathrm{~cd} 9 . \ldots \ldots . .8427 \mathrm{e}$ \\
\hline FORM2 & corrupt & 10477bc204af1.....2058e & $\mathrm{d} 41 \mathrm{~d} 8 \mathrm{~cd} 9 . . . . . .8427 \mathrm{e}$ \\
\hline GAMBAR1 & disappear & $33 \mathrm{ac} 333658695 \ldots . . \mathrm{b} 25 \mathrm{ab}$ & - \\
\hline
\end{tabular}

$\overline{\text { Rizdqi Akbar Ramadhan, Implementasi Metode NIJ Pada Fitur TRIM Solid State Drive Dengan Objek Sistem }}$ Operasi Windows, Linux, dan Macintosh 


\begin{tabular}{crrr} 
GAMBAR2 & disappear & $\mathrm{a} 22 \mathrm{~d} 7 \mathrm{~b} 5 \mathrm{~b} 268 \mathrm{df6} 4 \ldots . . \mathrm{fd} 4 \mathrm{a} 9$ & - \\
SLIDE1 & disappear & $\mathrm{fb} 9 \mathrm{~b} 95 \mathrm{c} 3 \mathrm{cb} 2 \ldots \ldots .1862$ & - \\
SLIDE2 & disappear & $\mathrm{d} 0 \mathrm{fcfadf9} 9031085 \ldots . \mathrm{fb} 60$ & - \\
FILM1 & disappear & f81b311b93e1....b807 & - \\
FILM2 & disappear & $\mathrm{e} 6 \mathrm{~d} 2084 \mathrm{a} 9 \mathrm{de} . . . .4 \mathrm{ab} 6$ & - \\
\hline
\end{tabular}

Selanjutnya pada objek simulasi pada sistem operasi Macintosh OSX Catalina 10.15.4 dengan arsitektur 64bit dapat dilihat pada Tabel 7 bahwa pada konfigurasi TRIM enable maupun konfigurasi TRIM disable didapatkan hasil bahwa tidak ada file yang berhasil terdeteksi kembali maupun recovery. Fakta lainnya, durasi eksaminasi pada sistem operasi MacOS Catalina tercatat memiliki durasi yang lebih panjang secara signifikan.

Tabel 7. Hasil Analisis Sistem Operasi MacOS Catalina

\begin{tabular}{|c|c|c|c|}
\hline TRIM enable & Status & Hash Value (pre-autopsy) & Hash Value (post-autopsy) \\
\hline LAGU1 & disappear & afbae4d76a516....c3df9a82 & - \\
\hline LAGU2 & disappear & 6c7b092771ff94.......760e5 & - \\
\hline DOKUMEN1 & disappear & f93ccfee 75 e $8 c . . . . . . . e 6 d 436$ & - \\
\hline DOKUMEN2 & disappear & c9a998879b0......b5fa4d10 & - \\
\hline FILE1 & disappear & c21d96078.....77b7d7 & - \\
\hline FILE2 & disappear & $615 \mathrm{e} 1 \mathrm{a} 485939 \ldots . .91 \mathrm{c} 220$ & - \\
\hline FORM1 & disappear & $621 \mathrm{~d} 21 \mathrm{e} 418 \ldots . . .0292 \mathrm{ef}$ & - \\
\hline FORM2 & disappear & 10477bc204af1.....2058e & - \\
\hline GAMBAR1 & disappear & $33 a c 333658695 \ldots . . . b 25 a b$ & - \\
\hline GAMBAR2 & disappear & a22d7b5b268df64......fd4a9 & - \\
\hline SLIDE1 & disappear & fb9b95c3cb2.....1862 & - \\
\hline SLIDE2 & disappear & d0fcfadf94031085...fb60 & - \\
\hline FILM1 & disappear & f81b311b93e1....b807 & - \\
\hline FILM2 & disappear & e6d2084a9de.....4ab6 & - \\
\hline TRIM enable & Status & Hash Value (pre-autopsy) & Hash Value (post-autopsy) \\
\hline LAGU1 & disappear & afbae4d76a516...c3df9a82 & - \\
\hline LAGU2 & disappear & 6c7b092771ff94.......760e5 & - \\
\hline DOKUMEN1 & disappear & f93ccfee 75 e8c........e6d 436 & - \\
\hline DOKUMEN2 & disappear & c9a998879b0 ......b5fa4d10 & - \\
\hline FILE1 & disappear & c21d96078......77b7d7 & - \\
\hline FILE2 & disappear & 615e1a485939.....91c220 & - \\
\hline FORM1 & disappear & $621 \mathrm{~d} 21 \mathrm{e} 418 \ldots . .0292 \mathrm{ef}$ & - \\
\hline FORM2 & disappear & $10477 b c 204 a f 1 \ldots . . .2058 \mathrm{e}$ & - \\
\hline GAMBAR1 & disappear & $33 \mathrm{ac} 333658695 \ldots . . . \mathrm{b} 25 \mathrm{ab}$ & - \\
\hline GAMBAR2 & disappear & a22d7b5b268df64......fd4a9 & - \\
\hline SLIDE1 & disappear & fb9b95c3cb2 $2 \ldots . .1862$ & - \\
\hline SLIDE2 & disappear & d0fcfadf94031085....fb60 & - \\
\hline FILM1 & disappear & f81b311b93e1.....b807 & - \\
\hline FILM2 & disappear & e6d2084a9de.....4ab6 & - \\
\hline
\end{tabular}

Berdasarkan hasil skenario simulasi dan analisis menggunakan 3 sistem operasi yang berbeda, Windows memiliki peluang untuk recovery paling besar, diikuti oleh Linux dan Macintosh dibelakanganya. [18] Ini merupakan tantangan investigator forensik dalam mencari dan eksplorasi bukti digital yang terdapat pada SSD. 


\section{KESIMPULAN}

Berdasarkan hasil penelitian dengan berbagai perangkat keras dan perangkat lunak dari 2 perspektif yang telah ditetapkan, didapatkan beberapa fakta. Linux Ubuntu mencatatkan rata-rata durasi waktu tersingkat dalam proses eksaminasi dan diteruskan oleh sistem operasi Windows 10. Sistem operasi MacOS Catalina secara signifikan memiliki durasi terpanjang dalam hal eksaminasi dengan rata-rata waktu tiga kali lipat lebih lama dibandingkan Linux Ubuntu dan Windows 10. Pada Windows 10 dalam persentase-nya pada konfigurasi TRIM enable, $0 \%$ dari 14 file tidak dapat recovery dan berstatus corrupt. Sedangkan pada TRIM disable, $85,7 \%$ file berhasil recovery dan $14,3 \%$ corrupt. Pada Linux Ubuntu presentase recovery pada TRIM enable adalah $0 \%$ dengan status disappear serta pada TRIM disable jumlah file recovery adalah $0 \%$ dengan catatan $28,5 \%$ corrupt dan 71,5\% disappear. Selanjutnya pada Macintosh Catalina presentase recovery sebesar $0 \%$ dan presentase disappear sebesar 100\%. Dalam hal recovery deleted files sistem operasi Windows 10 dengan file system NTFS memiliki potensi ditemukan artefak barang bukti digital lebih besar, baik dalam konfigurasi TRIM enable maupun TRIM disable, diikuti oleh sistem operasi Linux Ubuntu dengan file system ext4 dan secara signifikan pada sistem operasi MacOS Catalina dengan file system APFS tidak ditemukan sama sekali recovery deleted files yang mana hal ini akan menjadi obstacle kepada investigator forensik kedepannya. Secara sederhana terkait minimalnya recovery files diluar sistem operasi Windows 10 adalah SLEUTH KIT Autopsy yang bersifat native. Alternatif tools forensik digital yang bisa digunakan adalah ENCASE Forensic yang pada penelitian penulis sebelumnya memiliki kapabilitas lebih baik atas SLEUTH KIT Autopsy. OXYGEN Forensic termasuk alternatif lainnya, namun tools ini lebih idientik dengan investigasi mobile forensic. Bagi penelitian selanjutnya diharapkan untuk melakukan uji forensik SSD dengan konfigurasi menggunakan RAID 0 yang dimana konfigurasi ini menjadi tren yang akan berkembang dalam pengimplementasian arsitektur penyimpanan digital.

\section{UCAPAN TERIMA KASIH}

Penulis mengucapkan terima kasih kepada LLDIKTI Wilayah Kopertis X dalam skema Simlitabmas Penelitian Dosen Pemula (PDP) sebagai penyedia dana untuk realisasi berjalannya penelitian ini.

\section{DAFTAR PUSTAKA}

[1] Y. Prayudi and A. SN, "Digital Chain of Custody: State of The Art," Int. J. Comput. Appl., vol. 114, no. 5, pp. 1-9, 2015.

[2] R. A. Ramadhan, Y. Prayudi, and B. Sugiantoro, "Implementasi dan Analisis Forensika Digital Pada Fitur Trim Solid State Drive (SSD)," Teknomatika, vol. 9, no. 2, pp. 1-13, 2017.

[3] A. Aljaedi, D. Lindskog, P. Zavarsky, R. Ruhl, and F. Almari, "Comparative Analysis of Volatile Memory Forensics," IEEE Int. Conf. Privacy, Secur. Risk Trust IEEE Int. Conf. Soc. Comput., pp. 1253-1258, 2011.

[4] R. Hubbard, "Forensics Analysis of Solid State Drive ( SSD )," pp. 1-11, 2016.

[5] J. Wiebe, "Forensic Insight into Solid State Drives."

[6] F. F. N. Dezfoli, A. Dehghantanha, R. Mahmoud, N. F. B. M. Sani, and F. Daryabar, "Digital Forensic Trends and Future," Int. J. Cyber-Security Digit. Forensics, vol. 2, no. 2, pp. 48-76, 2013.

[7] N. Memon, "Challenges of SSD forensic analysis."

[8] P. M. Bednar and V. Katos, "SSD: New Challenges for Digital Forensics."

[9] M. Alazab and P. Watters, "Digital forensic techniques for static analysis of NTFS images," 4th Int. Conf. Inf. Technol. ICIT, 2009.

[10] M. N. Faiz, R. Umar, and A. Yudhana, "Live Forensics Implementation for Browser Comparison on Email Security," JISKa, vol. 1, no. 3, pp. 108-114, 2017.

Rizdqi Akbar Ramadhan, Implementasi Metode NIJ Pada Fitur TRIM Solid State Drive Dengan Objek Sistem Operasi Windows, Linux, dan Macintosh 
[11] S. Garfinkel, D. Malan, K. Dubec, C. Stevens, and C. Pham, "Disk Imaging with the Advanced Forensics Format, Library and Tools," Proc. IFIP WG 11.9 Int. Conf. Digit. Forensics, pp. 1-19, 2006.

[12] M. Rafique and M. N. A. Khan, "Exploring Static and Live Digital Forensics: Methods, Practices and Tools," Int. J. Sci. Eng. Res., vol. 4, no. 10, pp. 1048-1056, 2013.

[13] Z. Shah, A. N. Mahmood, and J. Slay, "Forensic Potentials of Solid State Drives."

[14] S. Mrdovic, A. Huseinovic, and E. Zajko, "Combining static and live digital forensic analysis in virtual environment," 2009 XXII Int. Symp. Information, Commun. Autom. Technol., no. August 2016, pp. 1-6, 2009.

[15] I. Riadi, R. Umar, and I. M. Nasrulloh, "Analisis Forensik Digital Pada Frozen Solid State Drive Dengan Metode National Institute of Justice (Nij)," Elinvo (Electronics, Informatics, Vocat. Educ., vol. 3, no. 1, pp. 70-82, 2018.

[16] N. Rahim, W. Wahab, Y. Idris, and L. Kiah, "Digital Forensics: An Overview of the Current Trends," Researchgate.Net, no. August 2016, 2014.

[17] N. Dwi and W. Cahyani, "FORENSICS ARISING CHALLENGES WHEN SSD IS HEADING FORWARDS REPLACING HDD," pp. 227-232.

[18] Belkasoft, "Recovering Evidence from SSD Drives in 2014: Understanding TRIM, Garbage Collection and Exclusions | Forensic Focus - Articles," Forensic Focus, pp. 1-8, 2014.

\section{BIOGRAFI PENULIS}

\begin{tabular}{|l|l|}
\hline & $\begin{array}{l}\text { Rizdqi Akbar Ramadhan meraih gelar Sarjana S1 di Universitas Islam Indonesia pada tahun } \\
2013 \text { dengan jurusan Teknik Informatika. Melanjutkan pendidikan S2 dan meraih gelar Master } \\
\text { pada tahun } 2016 \text { di Universitas Islam Indonesia. Konsentrasi yang dipelajari dan menjadi objek } \\
\text { tri dharma pengajaran, pengabdian, penelitian hingga kini adalah cabang ilmu Digital Forensik } \\
\text { dan memiliki Certified Hacking and Forensic Investigator (CHFI). Lahir di Pekanbaru dan } \\
\text { mengabdi sebagai pengajar di Universitas Islam Riau. }\end{array}$ \\
\hline $\begin{array}{l}\text { Desti Mualfah lahir di Jawa Tengah dan meraih gelar Sarjana S1 di Universitas Muhamadiyah } \\
\text { Magelang pada 2014 serta gelar Master S2 pada 2017 di Universitas Islam Indonesia. Memiliki } \\
\text { sertifikasi internasional dalam Certified Ethical Hacking (CEH) dan Certified Hacking and } \\
\text { Forensic Investigator (CHFI). Sejak tahun 2018 mengabdi sebagai pengajar di Universitas } \\
\text { Muhamadiyah Riau dan aktif melakukan penelitian terhadap cabang ilmu Jaringan Komputer } \\
\text { dan Digital Forensik. }\end{array}$ \\
\hline
\end{tabular}

